\title{
Identification of a novel human estrogen receptor- $\alpha$ splice variant able to enhance malignant biological behaviors of breast cancer cells
}

\author{
HUA ZHU ${ }^{1,2}$, YUE HUANG ${ }^{3}$, HELING SU $^{2}$, YILI MA ${ }^{2}$, YIMING TAO ${ }^{2}$, \\ D. JOSHUA LIAO ${ }^{4}$, YONGMING LIU ${ }^{2}$ and ZHENBO FENG ${ }^{1}$

\begin{abstract}
${ }^{1}$ Department of Pathology, The First Affiliated Hospital of Guangxi Medical University, Nanning, Guangxi 530021;
${ }^{2}$ Department of Biotechnology, Guilin Medical University, Guilin, Guangxi 541004; ${ }^{3}$ Department of Breast Surgery,

Affiliated Hospital of Guilin Medical University, Guilin, Guangxi 541001, P.R. China;

${ }^{4}$ Hormel Institute, The University of Minnesota, Austin, MN 55912, USA
\end{abstract}

Received October 8, 2016; Accepted January 12, 2018

DOI: $10.3892 / \mathrm{ol} .2018 .7970$

\begin{abstract}
Since the early 1990s, multiple human estrogen receptor- $\alpha$ (hER- $\alpha$ ) splice variants have been identified, of which the majority contain $\geq 1$ deleted exon, and some are expressed as proteins with modified functions from the wild-type $66 \mathrm{kDa}$ hER- $\alpha$ (ER- $\alpha 66)$. In the present study, a novel hER- $\alpha$ splice variant, ER- $\alpha 30$, was identified and cloned from clinical breast cancer tissue. The ER- $\alpha 30$ sequence lacked a ligand-binding domain and a ligand-dependent transcriptional activation domain but retained the $\mathrm{N}$-terminal transcriptional activation domain, the DNA-binding domain and a partial hinge domain, and possesses a unique 10-amino-acid domain. The expression of ER- $\alpha 30$ was associated with ER- $\alpha 66$-negative and progesterone receptor-negative breast cancer. The $30 \mathrm{kDa}$ protein was expressed in stably transfected MDA-MB-231 cells, and the overexpression of ER- $\alpha 30$ in MDA-MB-231 cells enhanced malignant biological behaviors, including cellular proliferation, migration and invasion in vitro. The results of the present study indicated that ER- $\alpha 30$ might represent a potential biomarker for breast cancer.
\end{abstract}

\section{Introduction}

Alternative splicing produces multiple mRNA splice variants from the same gene; thus, a limited number of genes can encode

Correspondence to: Professor Zhenbo Feng, Department of Pathology, The First Affiliated Hospital of Guangxi Medical University, 22 Shuangyong Street, Nanning, Guangxi 530021, P.R. China E-mail: guanghu1963@126.com

Professor Yongming Liu, Department of Biotechnology, Guilin Medical University, 1 Zhiyuan Street, Guilin, Guangxi 541004, P.R. China

E-mail: liuym@glmc.edu.cn

Key words: estrogen receptor- $\alpha$, splice variant, biological behaviours, breast cancer, MDA-MB-231 cells a variety of different proteins (1). Specific splice variants have been reported to serve significant roles in the development, clinical diagnosis and treatment of cancer (2). Human estrogen receptor- $\alpha$ (hER- $\alpha$ ) is a widely accepted predictive marker of the effectiveness of endocrine (anti-estrogen) therapy in patients with breast cancer (3). In general, ER- $\alpha$-positive patients respond effectively to anti-estrogens, including tamoxifen, whereas ER- $\alpha$-negative patients do not $(4,5)$. Despite this general pattern, a proportion of ER- $\alpha$-negative patients with breast cancer are responsive to anti-estrogen treatment (6). It is possible that ER- $\alpha$ is expressed in these patients, but that its pre-mRNA undergoes alternative splicing resulting in the expression of variant isoforms, the protein products of which cannot be detected using commercially available ER- $\alpha$ antibodies. These variants may be induced during the formation and progression of breast cancer, influencing the behavior of breast cancer cells via uncharacterized mechanisms, and potentially promoting the progression of breast cancer to more aggressive phenotypes, including loss of responsiveness to anti-estrogen treatment $(7,8)$.

In the present study, a novel $30 \mathrm{kDa}$ hER- $\alpha$ splice variant (ER- $\alpha 30)$, was identified, which is encoded by a distinct ER- $\alpha$ mRNA and enhanced the malignant biological behaviors of human breast cancer MDA-MB-231 cells.

\section{Materials and methods}

Clinical breast tumor tissues. Breast tumor tissues were collected from 33 female patients of breast invasive ductal carcinoma treated at the Affiliated Hospital of Guilin Medical University (Guangxi, China) between August 2013 and June 2014. The age of patients ranged from 37-81, with an average age of 56 years. The specimens were obtained during surgical resection, cut into $0.3-0.5 \mathrm{~cm}^{2}$ sections and stored in liquid nitrogen prior to experimentation. No patients had received chemotherapy or radiotherapy prior to surgery. The tumor stage was pathologically determined according to the American Joint Committee on Cancer staging system $(9,10)$. ER- $\alpha 66$, progesterone receptor (PR) and Erb-B2 receptor tyrosine kinase 2 (Her-2) expression statuses were determined 
by immunohistochemistry analysis in the hospital's pathology department. The present study was approved by the Human Ethics Committee of the Affiliated Hospital of Guilin Medical University (Guangxi, China) and informed consent was obtained from all patients.

ER- 230 cloning and expression in breast cancer tissue. Total RNA was extracted from 300-500 mg breast tumor tissues using TRIzol (Thermo Fisher Scientific, Inc., Waltham, MA, USA), according to the manufacturer's instructions. cDNA was then synthesized using $3 \mu \mathrm{g}$ total RNA and oligodT primers using a RevertAid First Strand cDNA Synthesis kit (Fermentas; Thermo Fisher Scientific, Inc.), according to the manufactuerer's protocol. The open-reading frame (ORF) of ER- $\alpha 30$ was amplified by semi-nested reverse transcription-polymerase chain reaction (RT-PCR) in two 30-cycle reactions. The thermocycling conditions were as follows: Round $1: 94^{\circ} \mathrm{C}$ for $5 \mathrm{~min}$, then 30 cycles of $94^{\circ} \mathrm{C}$ for $30 \mathrm{sec}, 58^{\circ} \mathrm{C}$ for $30 \mathrm{sec}$ and $72^{\circ} \mathrm{C}$ for $90 \mathrm{sec}$, completed at $72^{\circ} \mathrm{C}$ for $5 \mathrm{~min}$; round $2,94^{\circ} \mathrm{C}$ for $5 \mathrm{~min}$, then 30 cycles of $94^{\circ} \mathrm{C}$ for $30 \mathrm{sec}, 60^{\circ} \mathrm{C}$ for $30 \mathrm{sec}$ and $72^{\circ} \mathrm{C}$ for $90 \mathrm{sec}$, completed at $72^{\circ} \mathrm{C}$ for 5 min under the conditions recommended by the LA $\mathrm{Taq}^{\mathrm{TM}}$ kit (Takara Biotechnology Co., Ltd., Dalian, China). Primers were designed and synthesized by Shenggong, Biotechnology Co., Ltd. (Shanghai, China) for exon 1 (forward, 5'-ATGACCATGACCCTCCAC ACCAAAG-3') and exon 8 (outer reverse 1, 5'-GCAGCAGGG ATTATCTGAACCG-3' and inner reverse 2, 5'-GGAATG CGATGAAGTAGAGCC-3'), respectively, with the cDNAs used as a template for round 1 and the product of round 1 used as the template for round 2. Hypoxanthine phosphoribosyl transferase was used as an internal control (forward primer, 5'- GCTTTCCTTGGTCAGGCAGTA-3' and reverse primer, 5'-CGATGTCAATAGGACTCCAGATGT-3'). The RT-PCR product was then, sequenced by Shenggong, Biotechnology Co., Ltd., and homology was analyzed using the National Centre for Biotechnology Information Basic Local Alignment Search Tool (https://blast.ncbi.nlm.nih.gov/Blast.cgi). The association between ER- $\alpha 30$ expression status and clinical characteristics, including age, tumor size, tumor stage, lymph nodal status, ER- $\alpha 66$, PR, and Her-2 status, was analyzed.

Cell culture. The breast cancer MDA-MB-231 cell line [ER-a66(-), PR(-), Her-2(-)] were acquired from the Cell Bank of the Type Culture Collection of the Chinese Academy of Sciences (KunMing, China), and MCF-7 cell line [ER- $\alpha 66(+)]$ were provided as a gift from Professor Yiming Tao (Department of Biotechnology, Guilin Medical University, Guilin, China). All cells were cultured in DMEM-F12 (Gibco; Thermo Fisher Scientific, Inc.) containing 10\% fetal bovine serum (FBS; Gibco; Thermo Fisher Scientific, Inc.), $100 \mathrm{U} / \mathrm{ml}$ penicillin and $100 \mu \mathrm{g} / \mathrm{ml}$ streptomycin at $37^{\circ} \mathrm{C}$ and $5 \% \mathrm{CO}_{2}$.

Plasmid preparation and transfection. A 1,002-bp fragment from the PCR experiment was amplified and cloned into the corresponding sites of the expression vector, pEGFP-N1 (provided as a gift from Professor Heling $\mathrm{Su}$, Department of Biotechnology, Guilin Medical University, Guilin, China) [with deleted enhanced green fluorescent protein (EGFP)], with HindIII and BamHI. The cloning was then verified by sequencing (Shenggong, Biotechnology Co., Ltd., Shanghai,
China). Transfection was performed using Lipofectamine ${ }^{\circledR}$ 2000 (Thermo Fisher Scientific, Inc.), according to the manufacturer's protocol. MDA-MB-231 cells were seeded in a 6-well plate $24 \mathrm{~h}$ prior to transfection with the plasmids. Cells were washed twice with PBS and then cultured in $2 \mathrm{ml}$ antibiotic-free medium containing either pEGFP-N1/ER- $\alpha 30$ or the empty vector pEGFP-N1 plasmid with Lipofectamine ${ }^{\circledR} 2000(3 \mu \mathrm{g}$ plasmid, $5 \mu \mathrm{l}$ Lipofectamine, and $1.2 \times 10^{5}$ cells/well). After $48 \mathrm{~h}$, stably transfected cells were selected using $600 \mu \mathrm{g} / \mathrm{ml}$ geneticin (G418; Thermo Fisher Scientific, Inc.) for 2-3 weeks. The remaining surviving individual clones were pooled and expanded for further analysis.

Western blot analysis. Stably transfected MDA-MB-231 cells and MCF-7 cells [acted as the positive control of ER- $\alpha 66(+)$ without transfection] were lysed in radioimmunoprecipitation assay buffer (Beyotime Biotechnology Co., Ltd., Shanghai, China) containing $1 \mathrm{mmol} / \mathrm{l}$ phenylmethanesulfonyl fluoride. Protein quantification was performed according to the manufacturer's instructions of an Enhanced BCA Protein assay kit (Beyotime Biotechnology Co., Ltd.). A total of $20 \mu \mathrm{g}$ protein was separated by SDS-PAGE using a 5\% stacking gel and a $10 \%$ separating gel. The proteins were electro transferred onto a polyvinylidene difluoride membrane and blocked at room temperature in 3\% bovine serum albumin (Roche Diagnostics, Basel, Switzerland) in tris-buffered saline and $0.5 \%$ Tween-20 (TBST) for $30 \mathrm{~min}$. The membrane was then incubated with anti-ER- $\alpha$ (dilution, 1:100; cat. no. sc-7207, H-184; Santa Cruz Biotechnology, Inc., Dallas, TX, USA, provided as a gift from Professor Joshua Liao), and $\beta$-actin (dilution, 1:1,000; cat. no. AA128; Beyotime Biotechnology Co., Ltd.) primary antibodies overnight at $4^{\circ} \mathrm{C}$. Finally, the membrane was incubated with horseradish peroxidase-conjugated goat anti-rabbit (for ER- $\alpha$, cat. no. CW0103; CW, Biotechnology Co., Ltd., Beijing, China) or goat anti-mouse (for $\beta$-actin, cat. no. CW0102; CW, Biotechnology Co., Ltd.) secondary antibody (dilution, $1: 10,000)$ at room temperature for $1 \mathrm{~h}$. The protein bands were visualized using the BeyoECL Plus kit (Beyotime Biotechnology Co., Ltd.).

MTT assay. Transfected cells were seeded into 96-well plates at a density of 400 cells/well (5 wells were seeded for each experimental group) and maintained in serum-free medium (DMEM-F12, containing $100 \mathrm{U} / \mathrm{ml}$ penicillin and $100 \mu \mathrm{g} / \mathrm{ml}$ streptomycin) for $24 \mathrm{~h}$ (day 1 ), then replaced with fresh complete medium (DMEM-F12, containing 10\% FBS, $100 \mathrm{U} / \mathrm{ml}$ penicillin and $100 \mu \mathrm{g} / \mathrm{ml}$ streptomycin) and cultured for 5 days (day 2-6). Cell proliferation was evaluated daily by adding $10 \mu 15 \mathrm{mg} / \mathrm{ml} \mathrm{MTT}$, and incubation for $4 \mathrm{~h}$ at $37^{\circ} \mathrm{C}$. The supernatant was then removed and the purple formazan crystals were dissolved in $100 \mu \mathrm{l}$ DMSO at room temperature for $15 \mathrm{~min}$. Finally, absorbance was determined using a spectrophotometer, measured at $570 \mathrm{~nm}$. The relative proliferation rate was calculated by dividing the optical density value on each of the 5 days by the value on day 1 .

Monolayer colony formation assay. A total of 200 transfected cells were seeded in triplicate in 6-well plates. The cells maintained in complete medium, refreshed every 3 days. After 2 weeks, the medium was removed and the cells were fixed 


\section{A MTMTLHTKASGMALLHQIQGNELEPLNRPQLKIPLERPLGEVYLDSSKPAVYNYPEGAAYEFNAAA AANAQVYGQTGLPYGPGSEAAAFGSNGLGGFPPLNSVSPSPLMLLHPPPQLSPFLPHGQQVPYYLE NEPSGYTVREAGPPAFYRPNSDNRRQGGRERLASTNDKGSMAMESAKETRYCAVCNDYASGYHY GVWSCEGCKAFFKRSIQGHNDYMCPATNQCTIDKNRRKSCQACRLRKCYEVGMMKGGIRKDRRG VCVPQIYYFA}

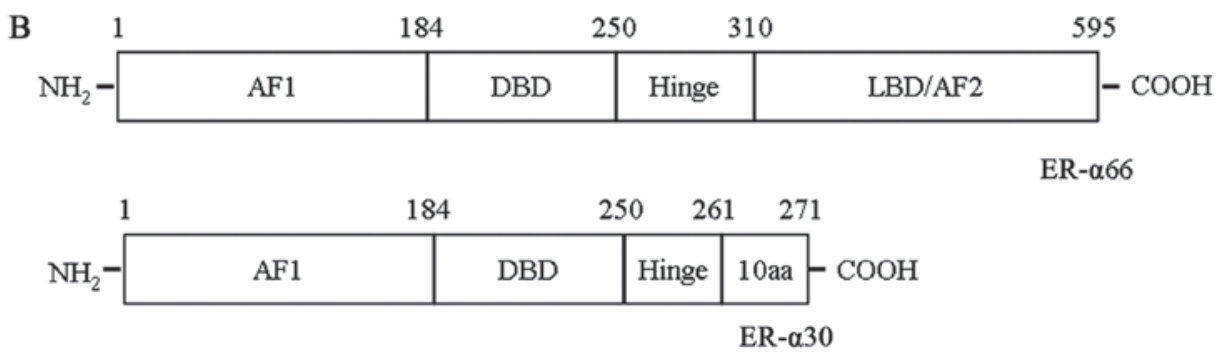

Figure 1. Novel hER- $\alpha$ splice variant, ER- $\alpha 30$. (A) The amino acid sequence of ER- $\alpha 30$, as predicted by its open-reading frame. The last 10 amino acids are underlined. (B) The protein domains of ER- $\alpha 66$ and ER- $\alpha 30$. The numbers refer to the amino acid sequence; and the boxes represent each domain. hER- $\alpha$, human estrogen receptor- $\alpha$; AF1, transcriptional activation domain; DBD, DNA-binding domain; LBD, ligand-binding domain; AF2, ligand-dependent transcriptional activation domain.

at room temperature for 10 min using $100 \%$ methanol, dyed at room temperature for $20 \mathrm{~min}$ with $0.1 \%$ crystal violet and washed with PBS. Visible colonies were counted to calculate the colony formation rate (\%) according to the following formula: Number of colonies/200 x 100.

Transwell migration and invasion assay. Transfected cells were incubated in serum-free DMEM for $24 \mathrm{~h}$. For the migration assay (without Matrigel), $100 \mu \mathrm{l}$ serum-free cell suspension containing $2 \times 10^{4}$ cells was directly added into the upper chambers of a Transwell plate $(8 \mu \mathrm{m}, 24-w e l l$ plate; Corning Incorporated, Corning, NY, USA). For invasion studies, Matrigel (BD Biosciences, Franklin Lakes, NJ, USA) was thawed overnight at $4^{\circ} \mathrm{C}$ and diluted with serum-free medium at a ratio of 1:8. The polycarbonate membranes of the Transwell inserts were coated with $50 \mu \mathrm{l}$ diluted Matrigel and incubated at $37^{\circ} \mathrm{C}$ for $1 \mathrm{~h}$. Next, $100 \mu \mathrm{l}$ serum-free cell suspension containing $4 \times 10^{4}$ cells was added to each upper chamber, and $500 \mu 1$ DMEM-F12 containing 10\% FBS was added to each lower chamber. Following incubation for $12 \mathrm{~h}$, the supernatant was removed from the upper chamber and cells unable to penetrate the membrane were carefully removed with a cotton swab. The Transwell membrane was then fixed at room temperature for $15 \mathrm{~min}$ with $4 \%$ paraformaldehyde, washed with PBS and dyed at room temperature for $20 \mathrm{~min}$ with $0.1 \%$ crystal violet. Images from 5 fields on each membrane were captured at x40 magnification using a light microscope and the number of penetrated cells fixed to the lower surface of the membrane was counted. Independent experiments were repeated $\geq 3$ times using 3 Transwell inserts for each repeat.

Statistical analysis. SPSS software (version 17.0; SPSS, Inc., Chicago, IL, USA) was used to perform all statistical analysis. The association between ER- $\alpha 30$ expression and clinicopathological characteristics was analyzed using Fisher's exact test. The results of the colony formation, migration and invasion assays are presented as the mean \pm standard error of the mean of repeated independent experiments. Comparisons between 2 groups were analyzed by Student's t-test subsequent to Levene's test. $\mathrm{P}<0.05$ was considered to indicate a statistically significant difference.

\section{Results}

Cloning of ER- $\alpha 30$. The ER- $\alpha 30$ ORF was amplified by semi-nested RT-PCR using RNA from clinical breast cancer tumor tissue. A 1,002-bp PCR fragment was purified, cloned and successfully sequenced. The sequence of exons 1, 2, 3 and 8 were identical to the DNA sequence of the ER- $\alpha 66$ genomic sequence. However, the fragment contained only partial segments of exons 4 and 6 , and was completely lacking exons 5 and 7 . The first 24 bp of exon 4 were directly spliced to the last 44 bp of exon 6 . The cDNA sequence encoded a protein 271 amino acids in length with a predicted molecular weight of $30 \mathrm{kDa}$ (Fig. 1A). ER- $\alpha 30$ differed from ER- $\alpha 66$ as it lacked a ligand-binding domain (LBD) and a ligand-dependent transcriptional activation domain (AF2). It retained the N-terminal transcriptional activation domain (AF1), the DNA-binding domain (DBD), a partial hinge domain and contained a unique 10 amino acid domain at the C-terminus (Fig. 1B).

ER- $\alpha 30$ expression is inversely associated with ER- $\alpha 66$ and $P R$ expression. A total of 33 breast tumor specimens were analyzed using semi-nested RT-PCR and sequence analysis, revealing that the 1,002-bp PCR fragment was amplified in 11 tumor tissues but not in the remaining 22 tumor tissues, indicating that 11 specimens $(33.3 \%)$ expressed ER- $\alpha 30$ mRNA (Fig. 2). It was also demonstrated that ER- $\alpha 30$ expression was negatively associated with ER- $\alpha 66$ and PR expression status (Table I). The ER- $\alpha 30$ expression frequency of ER- $\alpha 66$ and PR-negative tumors was higher than that for ER- $\alpha 66$ and PR-positive tumors (60 vs. $11.1 \%$, and 55.6 vs. $6.7 \%$, respectively). No associations were identified between ER- $\alpha 30$ expression and other clinical characteristics, including age, menopausal status, tumor size, tumor stage, lymph node status, or Her-2 status.

ER-a30 ORF encodes a $30 \mathrm{kDa}$ protein recognized by antibodies targeting the $N$-terminal AF1 of ER- $\alpha 66$. To confirm whether the cloned ER- $\alpha 30$ ORF expresses the predicted protein, it was transfected into the human breast cancer MDA-MB-231 cell line using the pEGFP-N1 expression vector. 
Table I. Association between ER- $\alpha 30$ expression and clinical characteristics.

\begin{tabular}{|c|c|c|c|}
\hline \multirow[b]{2}{*}{ Characteristic } & \multirow[b]{2}{*}{ Patients, n } & \multicolumn{2}{|c|}{$\begin{array}{c}\text { ER- } \alpha 30 \\
\text { expression status }\end{array}$} \\
\hline & & Positive & Negative \\
\hline \multicolumn{4}{|l|}{ Age, years } \\
\hline$\geq 50$ & 22 & 8 & 14 \\
\hline$<50$ & 11 & 3 & 8 \\
\hline \multicolumn{4}{|l|}{ Menopausal status } \\
\hline Premenopausal & 12 & 4 & 8 \\
\hline Postmenopausal & 21 & 7 & 14 \\
\hline \multicolumn{4}{|l|}{ Tumor size, cm } \\
\hline$\leq 2$ & 12 & 4 & 8 \\
\hline$>2$ & 21 & 7 & 14 \\
\hline \multicolumn{4}{|l|}{ Tumor stage } \\
\hline I & 2 & 0 & 2 \\
\hline II & 16 & 5 & 11 \\
\hline III & 15 & 6 & 9 \\
\hline \multicolumn{4}{|l|}{ Lymph node status } \\
\hline 0 & 14 & 5 & 9 \\
\hline$\geq 1$ & 19 & 6 & 13 \\
\hline \multicolumn{4}{|l|}{ ER- $\alpha 66$ status $^{\mathrm{a}}$} \\
\hline Positive & 18 & 2 & 16 \\
\hline Negative & 15 & 9 & 6 \\
\hline \multicolumn{4}{|l|}{ PR status ${ }^{\mathrm{a}}$} \\
\hline Positive & 15 & 1 & 14 \\
\hline Negative & 18 & 10 & 8 \\
\hline \multicolumn{4}{|l|}{ Her- 2 status } \\
\hline Positive & 22 & 9 & 13 \\
\hline Negative & 11 & 2 & 9 \\
\hline
\end{tabular}

${ }^{\mathrm{a}} \mathrm{P}<0.001$. ER- $\alpha$, estrogen receptor- $\alpha$; PR, progesterone receptor; Her-2, Erb-B2 receptor tyrosine kinase 2.

Whole-cell protein extracts from MDA-MB-231/ER- $\alpha 30$ cells (stably transfected with pEGFP-N1-ER- $\alpha 30$ ), MDA-MB-231/v cells (stably transfected with the pEGFP-N1 empty vector), and MCF-7 cells (control) were subjected to western blot analysis using a polyclonal antibody targeting amino acids 2-185 of ER- $\alpha 66$. Visualization of the membrane revealed the presence of a $30 \mathrm{kDa}$ protein band in the MDA-MB-231/ER- $\alpha 30$ cells, but not in the MDA-MB-231/v cells or the MCF-7 cells. Meanwhile, a $66 \mathrm{kDa}$ protein band was visualized in the MCF-7 cells but not the MDA-MB-231/ER- $\alpha 30$ cells or the MDA-MB-231/v cells. These results indicated that the isolated ORF expressed the predicted protein, which was recognized by the anti-ER- $\alpha 66$ antibody (Fig. 3).

Overexpression of ER- $\alpha 30$ in MDA-MB-231 cells enhances cell proliferation, migration, and invasion. To investigate the effect of ER- $\alpha 30$ overexpression on the proliferation ability of MDA-MB-231 cells, MTT and monolayer colony formation assays were performed. As demonstrated

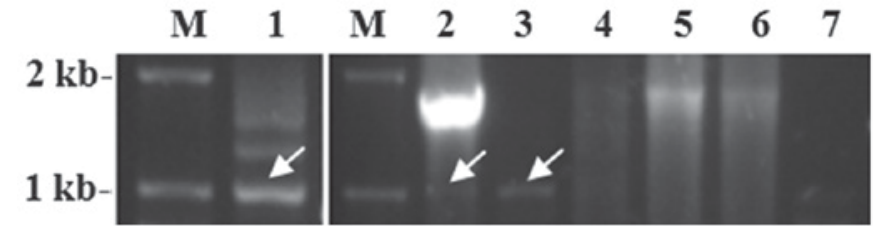

Figure 2. ER- $\alpha 30$ expression in clinical breast cancer tissues was analyzed using semi-nested reverse transcription-polymerase chain reaction. The electrophoresis results of 7 samples are provided. The numbers represent the serial number of the specimen, and the white arrows indicate the 1,002-bp fragment of ER- $\alpha 30$. ER- $\alpha$, estrogen receptor- $\alpha$; M, DL2000 marker.

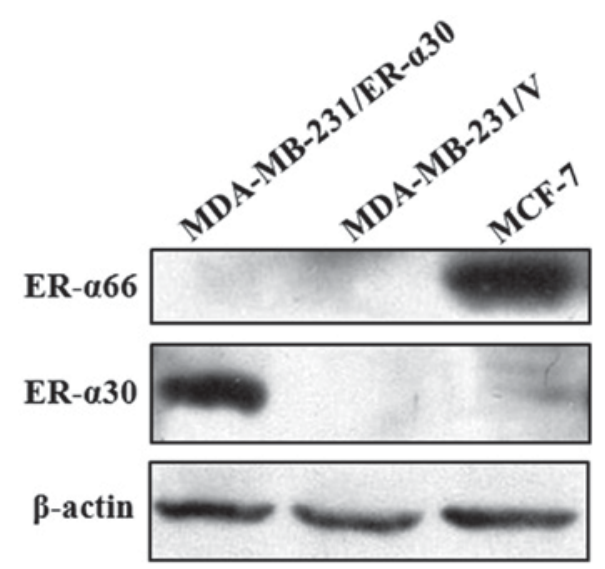

Figure 3. Western blot analysis confirmed that ER- $\alpha 30$ is expressed in MDA-MB-231/ER- $\alpha 30$ ER- $\alpha 30$-overexpresing cells, but not in cells transfected with the MDA-MB-231/v empty-vector or MCF-7 control cells. ER- $\alpha$, estrogen receptor- $\alpha$.

in Fig. 4A, MDA-MB-231/ER- $\alpha 30$ cells exhibited a more rapid rate of proliferation than did MDA-MB-231/v control cells. Furthermore, the monolayer colony-formation assay revealed that MDA-MB-231/ER- $\alpha 30$ cells exhibited a greater colony-formation ability than MDA-MB-231/v cells $(78.5 \pm 3.5$ vs. $40.3 \pm 1.7 \%$; Fig. 4B). To determine whether ER- $\alpha 30$ expression modulated the migratory and invasive abilities of breast cancer cells, a Transwell assay was performed. The MDA-MB-231/ER- $\alpha 30$ cells exhibited a greater migratory ability than the control cells $(184.7 \pm 24.3$ vs. $99.3 \pm 24.8$ cells; Fig. 4C and D). The MDA-MB-231/ER- $\alpha 30$ cells were also more invasive than the control cells $(124.2 \pm 12.1$ vs. $79.7 \pm 15.9$, respectively; Fig. 4C and D).

\section{Discussion}

In the present study, ER- $\alpha 30$, a novel splice variant of hER- $\alpha$, was cloned from clinical breast cancer tissue. In this variant, the first 24 bp of exon 4 were directly spliced to the last 44 bp of exon 6 of the hER- $\alpha$ genomic sequence. As exon 5 and 7 were completely deleted, the ORF of ER- $\alpha 30$ was predicted to encode a truncated protein of $30 \mathrm{kDa}$. The protein differed from the full-length hER- $\alpha$ (ER- $\alpha 66)$ as it lacked a segment of the hinge domain, the LBD and AF2, but possessed a unique C-terminal 10-amino-acid domain. The predicted truncated $30 \mathrm{kDa}$ protein was then overexpressed in MDA-MB-231 cells, as confirmed by a western blot assay using an antibody directly targeting the N-terminal AF1 of ER- $\alpha 66$. 
A
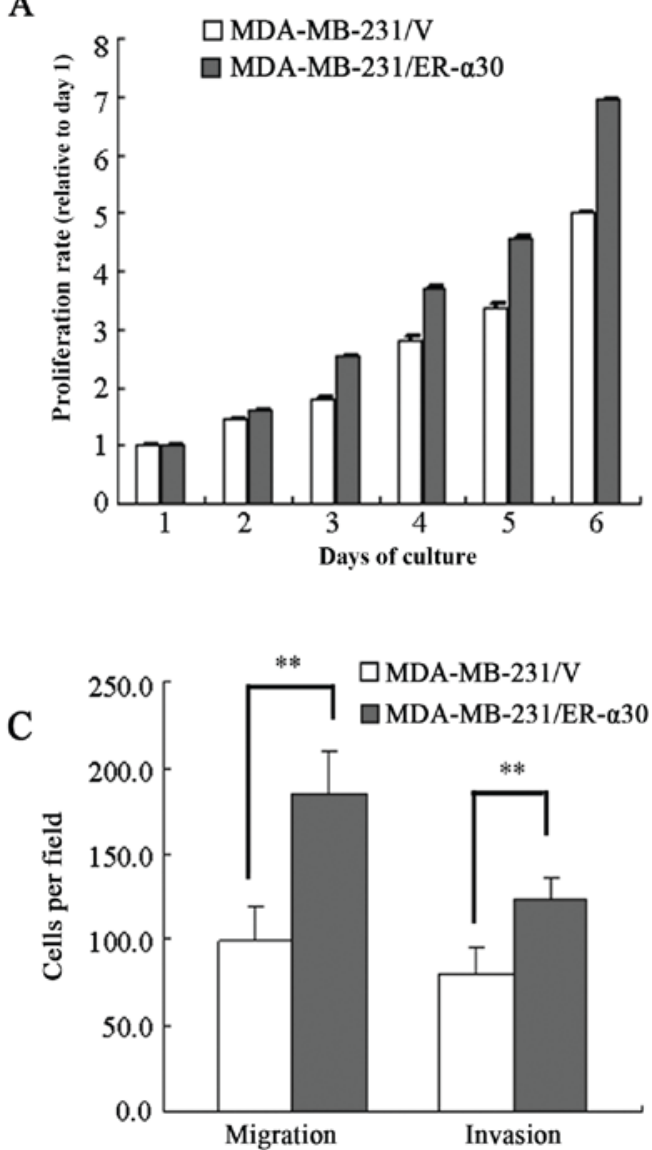

B
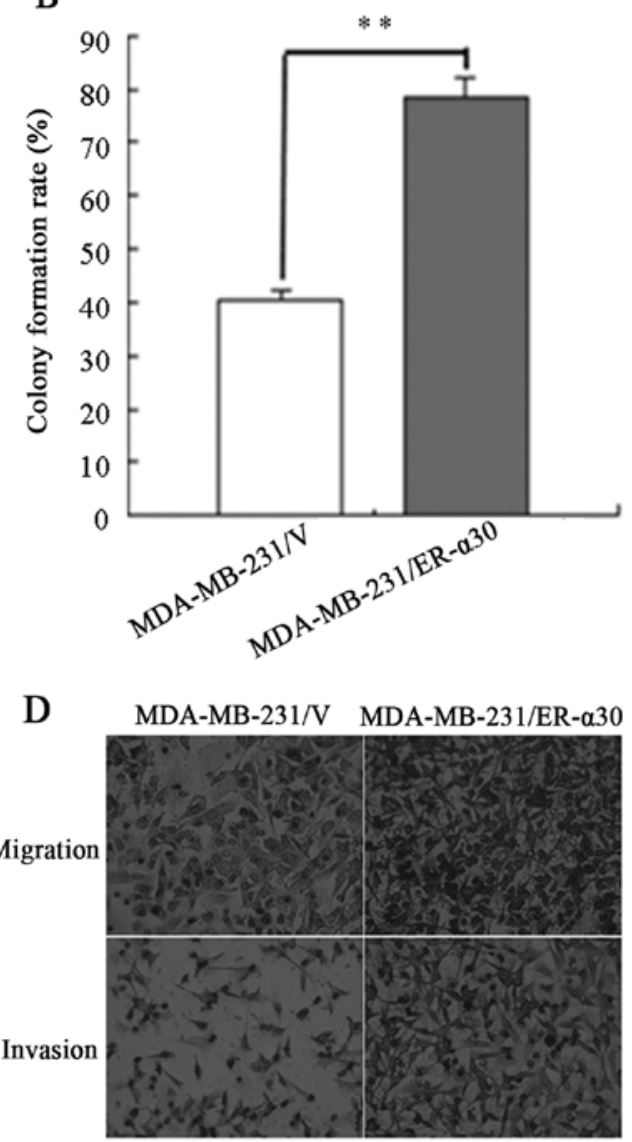

Figure 4. Overexpression of ER- $\alpha 30$ in MDA-MB-231 cells enhanced cellular proliferation, migration and invasion. (A) The proliferation rate of MDA-MB-231/v and MDA-MB-231/ER- $\alpha 30$ cells, relative to day 1, was analyzed by MTT assay. (B) The colony formation rate of MDA-MB-231/v and MDA-MB-231/ER- $\alpha 30$ cells was determined using a colony-formation assay. (C) The migratory and invasive abilities of MDA-MB-231/v and MDA-MB-231/ER- $\alpha 30$ cells were investigated by Transwell migration and invasion assays. (D) Representative photomicrographs (x40, magnification) of migrated/invasive MDA-MB-231/v and MDA-MB-231/ER- $\alpha 30$ cells. ${ }^{* *} \mathrm{P}<0.001$. ER- $\alpha$, estrogen receptor- $\alpha$.

It is likely that ER- $\alpha 30$ has not been previously identified in clinical specimens because the anti-ER- $\alpha 66$ antibody that targets the LBD is not present in this variant (11-13). With intact AF1 and DBD domains, ER- $\alpha 30$ may still function as a nuclear transcription factor, similar to ER- $\alpha 66$, mediating the traditional genomic signaling pathway. However, the C-terminal 10-amino-acid domain that is substituted for the last 335 amino acids of the LBD/AF2 domains indicates that ER- $\alpha 30$ may possess different transcriptional activity from the full-length protein. For example, it may exhibit a different ligand response profile to ER-a66. Alternatively, it may function as a negative inhibitor of the estrogen-signal response mediated through the ER- $\alpha 66$ AF2 domain, similar to ER- $\alpha 46$, which also lacks the AF1 domain and strongly represses AF1 activity of ER- $\alpha 66(14,15)$.

ER- $\alpha 30$ mRNA was expressed in 11/33 (33\%) breast cancer tissue specimens. As 2 adjacent normal breast tissues were not collected and the quality of total RNA from 4 adjacent normal tissues was too poor to be used for analysis, 5 adjacent normal tissues from of the 11 ER- $\alpha 30$-positive patients were also analyzed. Amplification of ER- $\alpha 30$ derived from the 5 adjacent normal breast tissues was unsuccessful (data not shown). Therefore, we hypothesized ER- $\alpha 30$ is mainly expressed in breast cancer tumor tissue. Furthermore, the association analysis of ER- $\alpha 30$ expression and clinical characteristics demonstrated that ER-a66- and PR-negative breast tumor tissues exhibited expression of the ER- $\alpha 30$ variant more frequently than ER- $\alpha 66-$ and PR-positive breast cancer tumors. This indicates that ER- $\alpha 30$ may inhibit the expression of ER- $\alpha 66$ and PR proteins, functioning as a negative regulation variant. However, no significant associations between ER- $\alpha 30$ expression and other clinical characteristics were identified, which is possibly due to the limited number of samples.

The ER- $\alpha 30$ expression status of the MDA-MB-231 cell line was analyzed using semi-nested RT-PCR, which revealed that the 1,002-bp PCR fragment was not expressed in this cell line (data not shown). ER- $\alpha 30$ overexpression induced in MDA-MB-231 cells was to investigate the potential function of ER- $\alpha 30$. It was demonstrated that ER- $\alpha 30$ overexpression promoted cell proliferation, migration, and invasion, indicating that ER- $\alpha 30$ may bind DNA through the retained DNA-binding domain to activate the transcription of specific target genes through the retained AF1 domain. ER-negative breast cancer exhibits higher rates of metastasis and recurrence than ER-positive breast cancer (16). The results of the present study indicated that ER- $\alpha 30$ may be associated with ER-negative breast cancer, and thus that it may be a potential biomarker for ER-negative breast cancer. ER- $\alpha 30$ expression was also analyzed in MCF-7 cells and negative results were achieved (Fig. 3). This conclusion would be strongly supported 
by performing a gene-silencing assay in a cell line exhibiting default ER- $\alpha 30$ expression.

In summary, a novel hER- $\alpha$ splice variant, ER- $\alpha 30$, was identified in the present study, and its function was preliminarily investigated. However, further characterization and validation is required, as are further studies to determine the significance of ER- $\alpha 30$ in human breast cancer. Future investigation should include the development of an antibody targeted to the unique 10-amino-acid domain of ER- $\alpha 30$ to characterize the expression pattern of ER- $\alpha 30$ in normal and breast cancer tissues, the mutual regulation between ER- $\alpha 30$ and ER- $\alpha 66$, and the mechanism by which ER- $\alpha 30$ enhances malignant biological behaviors. These studies will provide novel insights into the complex biological aspects of breast cancer.

\section{Acknowledgements}

Not applicable.

\section{Funding}

This study was supported by the Guangxi Provincial Natural ScienceFoundation of China (grant no.2013GXNSFBA019189).

\section{Availability of data and materials}

The data generated in this study are available from the corresponding upon reasonable request.

\section{Authors' contribution}

$\mathrm{HZ}$ performed the majority of the experiments and wrote the manuscript. YH and YM participated in experiments and sample collection. HS, YT and DJL provided materials and methods support. YL and ZF designed the experiments and contributed to the manuscript writing.

\section{Ethics approval and consent to participate}

The present study was approved by the Human Ethics Committee of the Affiliated Hospital of Guilin Medical University (Guangxi, China) and informed consent was obtained from all patients.

\section{Consent for publication}

Patients provided written informed consent for the publication of their data.

\section{Competing interests}

The authors declare that they have no competing interests.

\section{References}

1. Venables JP, Klinck R, Koh C, Gervais-Bird J, Bramard A, Inkel L, Durand M, Couture S, Froehlich U, Lapointe E, et al: Cancer-associated regulation of alternative splicing. Nat Struct Mol Biol 16: 670-676, 2009.

2. Chen J and Weiss WA: Alternative splicing in cancer: Implications for biology and therapy. Oncogene 34: 1-14, 2015.

3. Ishunina TA and Swaab DF: Estrogen receptor-alpha splice variants in the human brain. Gynecol Endocrinol 24: 93-98, 2008.

4. Dunnwald LK, Rossing MA and Li CI: Hormone receptor status, tumor characteristics, and prognosis: A prospective cohort of breast cancer patients. Breast Cancer Res 9: R6, 2007.

5. Goldhirsch A, Glick JH, Gelber RD, Coates AS, Thürlimann B and Senn HJ; Panel members: Meeting highlights: International expert consensus on the primary therapy of early breast cancer 2005. Ann Oncol 16: 1569-1583, 2005.

6. Huang B, Warner M and Gustafsson JÅ: Estrogen receptors in breast carcinogenesis and endocrine therapy. Mol Cell Endocrinol 418 (Pt 3): 240-244, 2015.

7. Li G, Zhang J, Jin K, He K, Zheng Y, Xu X, Wang H, Wang H, Li Z, $\mathrm{Yu} \mathrm{X}$, et al: Estrogen receptor-a36 is involved in development of acquired tamoxifen resistance via regulating the growth status switch in breast cancer cells. Mol Oncol 7: 611-624, 2013.

8. Penot G, Le Péron C, Mérot Y, Grimaud-Fanouillère E, Ferrière F, Boujrad N, Kah O, Saligaut C, Ducouret B, Métivier R and Flouriot G: The human estrogen receptor-alpha isoform hERalpha46 antagonizes the proliferative influence of hERalpha66 in MCF7 breast cancer cells. Endocrinology 146: 5474-5484, 2005.

9. Harris L, Fritsche H, Mennel R, Norton L, Ravdin P, Taube S, Somerfield MR, Hayes DF and Bast RC Jr; American Society of Clinical Oncology: American Society of Clinical Oncology 2007 update of recommendations for the use of tumor markers in breast cancer. J Clin Oncol 25: 5287-5312, 2007.

10. Singletary SE, Allred C, Ashley P, Bassett LW, Berry D, Bland KI, Borgen PI, Clark G, Edge SB, Hayes DF, et al: Revision of the american joint committee on cancer staging system for breast cancer. J Clin Oncol 20: 3628-3636, 2002.

11. Denger S, Reid G, Kos M, Flouriot G, Parsch D, Brand H, Korach KS, Sonntag-Buck V and Gannon F: ERalpha gene expression in human primary osteoblasts: Evidence for the expression of two receptor proteins. Mol Endocrinol 15: 2064-2077, 2001.

12. Li L, Haynes MP and Bender JR: Plasma membrane localization and function of the estrogen receptor alpha variant (ER46) in human endothelial cells. Proc Natl Acad Sci USA 100: 4807-4812, 2003.

13. Wang Z, Zhang X, Shen P, Loggie BW, Chang Y and Deuel TF: Identification, cloning, and expression of human estrogen receptor-alpha36, a novel variant of human estrogen receptor-alpha66. Biochem Biophys Res Commun 336: 1023-1027, 2005.

14. Flouriot G, Brand H, Denger S, Metivier R, Kos M, Reid G, Sonntag-Buck V and Gannon F: Identification of a new isoform of the human estrogen receptor-alpha (hER-alpha) that is encoded by distinct transcripts and that is able to repress hER-alpha activation function 1. EMBO J 19: 4688-4700, 2000.

15. Márquez DC and Pietras RJ: Membrane-associated binding sites for estrogen contribute to growth regulation of human breast cancer cells. Oncogene 20: 5420-5430, 2001.

16. Parl FF, Schmidt BP, Dupont WD and Wagner RK: Prognostic significance of estrogen receptor status in breast cancer in relation to tumor stage, axillary node metastasis, and histopathologic grading. Cancer 54: 2237-2242, 1984. 